\title{
Quality characteristics of soft persimmon spread prepared with different functional saccharides
}

\author{
Ji-Young Choi ${ }^{1}$, Mun-Gyeong $\mathrm{Cho}^{2}$, Kwang-Deog Moon ${ }^{1 *}$ \\ ${ }^{1}$ School of Food Science and Technology, Kyungpook National University, Daegu 41566, Korea \\ ${ }^{2}$ Agricultural Research and Extension Services, Sangju Persimmon Research Institute, Sangju 37268, Korea
}

\section{기능성 당 종류에 따른 홍시 스프레드의 품질 특성 \\ 최지영 ${ }^{1} \cdot$ 조문경 ${ }^{2} \cdot$ 문광덕 $^{1 *}$ \\ 1경북대학교 식품공학부 식품생물공학전공, ${ }^{2}$ 경상북도농업기술원 상주감연구소}

\begin{abstract}
Soft persimmon spreads with four different functional saccharides were prepared for reducing the amount of excess sugar, and their quality characteristics were analyzed. CON1 had $40 \%$ sucrose added in weight, while CON2, XLT, IMO, FTO and MTD had $20 \%$ of sucrose, xylitol, isomalto-oligosaccharide, fructo-oligosaccharide, and maltodextrin added in weight, respectively. The proximate composition, soluble solid content, $\mathrm{pH}$, total acidity, color, viscosity, tannin content, lycopene content, and glucose dialysis retardation index of the spreads with different saccharides were analyzed and compared. The proximate composition of the spreads was summarized as follows: $49-58 \%$ moisture, 0.29- $0.58 \%$ crude protein, $0.02-0.10 \%$ crude fat, $0.32-0.37 \%$ crude ash, $40-50 \%$ carbohydrates, and $0.26-0.49 \%$ crude fiber. The total soluble solid of the spread containing IMO was $41.00{ }^{\circ}$ Brix, which was significantly lower than that of the control spread (CON1) of $59.33{ }^{\circ}$ Brix. The viscosity of the spread containing MTD was the highest, that is, $43,733 \mathrm{cp}$, while the spread with IMO had the lowest value of 17,600 $\mathrm{cP}$. The content of lycopene in the spread with IMO was the highest as $58.99 \mathrm{mg} / \mathrm{kg}$. The spread containing MTD indicated the most efficient glucose dialysis retardation index. There were no significant differences in the $\mathbf{p H}$, total acidity, tannin content, color value, and sensory evaluation between the samples( $>>0.05)$. Therefore, in terms of reducing sugar content in the spread, IMO exhibited the optimum result.
\end{abstract}

Key words : soft persimmon, saccharides, spread, isomalto oligosaccharide, lycopene

\section{서 론}

감나무(Diospyros kaki Thunb.)는 한국, 중국, 일본 등 온 대아시아 지역이 주 원산지이다. 감 과실은 $18 \%$ 의 많은 당분 을 함유하고 있고, 열량이 높을 뿐만 아니라 비타민 A, C, 가 용성 탄닌과 무기염류가 풍부하여 고대로부터 설사, 이뇨, 지 혈, 숙취 제거, 기침, 기관지염, 고혈압 등에 약리작용이 있다고
알려져 있는 전통과일 중의 하나이다(Lee 등, 1994). 또한 감 에는 페놀성 화합물인 catechin, epicatechin, epicatechin gallate, epigallocatechin, epigallocatechin gallate 등의 기능 성 물질이 다량 함유되어 있어 항산화기능(Lee 등, 2015), 항 균, 항종양작용 및 중금속 제거능과 같은 생리활성이 보고되 었다(Seo 등, 2000). 감은 1998년부터 유럽(이탈리아, 스페인 등)에서 본격적으로 재배되기 시작하면서 유럽에서는 토마토

*Corresponding author. E-mail : kdmon@knu.ac.kr, Phone : +82-53-950-5773, Fax : +82-53-950-6772

Received 21 December 2020; Revised 15 January 2021; Accepted 27 January 2021.

Copyright (c) The Korean Society of Food Preservation.

This is an Open Access article distributed under the terms of the Creative Commons Attribution Non-Commercial License (http://creativecommons.org/licenses/by-nc/4.0) which permits unrestricted non-commercial use, distribution, and reproduction in any medium, provided the original work is properly cited. 
다음으로 떠오르는 lycopene 급원으로 각광받고 있다. 홍시 의 적색은 lycopene이 대표적인 색소로 유럽 품종은 53.4 $\mathrm{mg} / \mathrm{kg}$ 함량을 가지고 있어(de Ancos 등, 2000) 토마토(30.2 $\mathrm{mg} / \mathrm{kg}$ )보다 훨씬 많이 함유하고 있다(Hwang과 Bowen, 2004). 홍시의 lycopene에 대해 연구되어 있다. Lycopene은 항산화효과, 항암효과와 항염증효과가 있다고 알려져 있다 (Heber와 Lu, 2002; Stahl 등, 2001). 또한 lycopene은 전립선 암 억제 효과 등이 있는 것으로 보고되어 있다(Giovannucci 등, 2002). 홍시에도 토마토만큼 lycopene의 함량이 존재하는 것으로 알려져 있지만, 이에 대한 연구는 미비한 편이다.

잼류의 가공 제품으로 스프레드(spread)가 있다. 스프레드 는 나이프를 사용해 빵이나 크래커 등에 바르는 음식을 말하 며, 어원은 '펼치다'라는 의미를 가진 영어단어 스프레드 (spread)에서 유래했다. 주로 담백한 음식의 풍미 및 감촉을 높여주기 위해 사용되며, 음식을 찍어먹는 것이 아닌 음식에 발라먹는다는 특징을 가지고 있다. 한편, 스프레드 제조에 설 탕이 많이 함유되어 기피하는 경향이 있다(McKee 등, 2002). 이에 대한 해결 방안으로 설탕에 비교하여 열량이 낮은 저열 량 또는 무설탕 스프레드가 제조되고 있다. 설탕 대체 물질로 는 당알코올(자일리톨, 말티톨 등) 또는 단당류가 2-8개 정도 결합한 탄수화물인 올리고당이 있으며, 당알코올은 충치 예방 효과(Maguire 등, 2000) 및 혈당 상승억제(Felber 등, 1987) 등의 기능성도 부여할 수 있는데, 자일리톨은 당알코올계 대 표적인 감미료로 당을 환원시켜 설탕에 비해 당알코올이 더 느리게 인체에 흡수되는 점이 당뇨 환자에게는 상당히 유리 하다(An 등, 2010). 또한 자일리톨은 천연 소재 감미료로 혈 당치를 상승시키지 않으며, 설탕과 유사한 당도를 지니고 있 어 인슐린 비의존성 당뇨 환자를 위한 중요한 당 대체원료로 의 이용은 물론 식품, 화장품, 의약품 등의 생산 원료로 그 기능성이 점차 확대되고 있을 뿐만 아니라, 최근에는 다이어 트 제품 및 골다공증 제품 등에서도 이용범위가 확대되고 있 다(Choi 등, 2013; Malinda 등, 2000). 올리고당은 단당류가 2-8개 정도 결합한 당질이며, 소화 효소에 의해 분해되지 않 는 당질을 일컫는다(Yun 등, 1992). 올리고당은 그 구조에 따 라 프락토 올리고당, 이소말토 올리고당, 갈락토올리고당, 자 일로올리고당, 키토올리고당 등이 있다. 그 중에서도, 이소말 토 올리고당은 전분을 원료로 해서 만든 감미료로서, 비발효 성 당으로 벌꿀에 존재하는 천연의 식품성분으로 알려져 있 다. 칼로리는 설탕의 $1 / 2$ 정도이며, 우수한 감미특성, 전분질 식품의 노화방지 효과, 보습성 및 장내에 존재하는 비피터스 균의 유용 세균 증식, 충치를 예방하는 효과 등 여러 가지 기 능성을 가지고 있다(Kwon과 Yuk, 1994). 프락토 올리고당은 우엉, 양파, 마늘, 바나나 등 천연식품에서도 소량 함유되어 있고, 감미도는 설탕의 $20-40 \%$ 정도이며 장내 소화효소에 의해 분해되지 않고 칼로리가 거의 없으며(Yun, 1996), 충치
예방, 장내 유용세균 증식, 장의 운동촉진으로 변비개선 효과 가 보고되어 요구르트, 차, 빵, 프리믹스 제품 등에 첨가하여 사용하고 있다. 말토덱스트린은 포도당이나 설탕에 비해 용 해도는 떨어지나 수화력이 크므로 보습성 또는 보수성이 크 다. 또한 대장 박테리아에 의해 분해되어 프로피온산과 단쇄 지방산을 생성하여 지방산합성 억제를 통해 혈청 콜레스테롤 수준을 감소시켜 대장암을 예방한다고 보고되고 있다(Seol 등, 2003).

감은 가공적성이 낮지만 식품 가공소재로써 가치가 높은 것으로 여겨져, 생과나 건조품 등 전통적 소비형태 이외의 최 근에는 고부가가치 향상을 위한 다양한 가공식품으로 개발되 고 있다(Lim 등, 2012). 또한 감 과실은 항산화, 알코올대사 촉진(Kim, 1999; Nam과 Kim, 2011; Seo와 Choi, 2007), 항 미생물, 항돌연변이, 지질대사 개선(Park, 2014) 등의 효과를 과학적으로 구명되어 건강기능식품으로 개발 중이며, 와인 (Lee 등, 2006), 퓨레, 동결홍시(Ann 등, 2007), 식초, 주스 (Kim 등, 1999), 잼, 조청 등의 가공식품으로도 개발되어 있 다(Kim 등, 2011).

따라서 본 연구에서는 약리작용과 기능성을 가진 홍시의 다양한 용도개발의 일환으로 홍시 스프레드 제조를 한 후 제 조 시 과다한 설탕의 양을 줄이고자 기능성 당을 첨가하여 제조한 후 여러 가지 품질특성 분석을 실시하여 홍시 스프레 드를 제조함에 있어 가장 적합한 기능성 당을 제시하고자 하 였다.

\section{재료 및 방법}

\section{실험재료}

본 연구에 사용한 홍시는 상주 감 시험장에서 수확한 떫은 감을 연화처리한 후 홍시로 만들고, $-20^{\circ} \mathrm{C}$ 에서 냉동 보관하였 다. 필요 시 상온에 3 시간 동안 해동하여 스프레드의 원료로 사용하였다. 순도 $99.8 \%$ 이상의 정백당(white sugar, Beksul, Cheiljedang, Incheon, Korea), 이소말토 올리고당(isomaltooligosaccharide $40 \%$ 이상, Chungjungone, Seoul, Korea), 프 락토 올리고당(fructo-oligosaccharide 50\% 이상, Beksul, Cheiljedang, Ansansi, Korea)을 시중에서 구입하여 사용하였 으며, 자일리톨(xylitol $100 \%$, Zhejiang Huakang Pharmac, China), 말토덱스트린(maltodextrin, DE 14-20, Daesang, Gunsan, Korea), 로커스트콩검(locust bean gum, LBG Sicilia, Italy)을 구입하여 사용하였다.

\section{홍시 및 홍시 스프레드 제조}

수확된 떫은 감을 연화제(에틸렌 가스발생제)와 밀봉 포장 하여 $25^{\circ} \mathrm{C}$ 항온실에 4 일간 처리한 후 2 일간 상온에서 환기시 켜 홍시를 제조하고, $-20^{\circ} \mathrm{C}$ 에서 냉동보관하며 사용했다. 시료 
는 온수로 세척 후 3 시간 동안 해동하여 씨와 껍질을 제거한 후 마쇄하여 시료로 사용하였다.

홍시스프레드 제조를 위한 모든 배합비율은 예비실험을 통해 결정되었다. 먼저 마쇄된 홍시에 감미료를 첨가한 후, 30 분간 가열한 뒤 로커스트콩검을 첨가하여 10 분 더 가열하 였다. 그런 다음 살균된 병에 담은 뒤 실험을 진행하였다. 배 합비는 Table 1에 나타내었다.

\section{일반성분 분석}

홍시 및 홍시 스프레드의 수분함량, 조지방, 조단백질, 조회 분은 2020년 식품의약품안전처에서 고시한 식품공전의 일반 시험법 기준으로 분석하였으며, 수분함량은 $105^{\circ} \mathrm{C}$ 상압가열 건조법에 준하여 drying oven(VS-1202D3, Vision Scientific Co., Daejeon, Korea)을 이용하였다. 조단백질은 Kjeldahl 법, 조지방함량은 Soxhelts 추출법, 조섬유는 HennebergStohmann 개량법(Rittich 등, 1985)에 의하여 분석하였고, 조 회분은 $550^{\circ} \mathrm{C}$ 의 회화로에서 직접 회화법으로 분석하였다. 각 분석 결과는 3 회 반복하여 얻은 평균값으로 나타내었다.

\section{가용성 고형분 함량, $\mathrm{pH}$ 및 산도 측정}

가용성 고형분 함량 측정은 시료 $10 \mathrm{~g}$ 을 증류수 $90 \mathrm{~mL}$ 로 희석하여 $3,000 \mathrm{rpm}$ 으로 10 분간 원심분리 후 여과하고 상층 액만 취하여 굴절 당도계(Master- $\alpha$, Atago Co., Tokyo, Japan) 로 3 회 반복 측정한 후, 평균값을 구하여 ${ }^{\circ} \mathrm{Brix}$ 로 표시하였 다. $\mathrm{pH}$ 는 $\mathrm{pH}$ meter로 3 회 반복 측정한 후, 평균값으로 나타 냈으며, 산도는 $5 \mathrm{~g}$ 의 시료에 증류수 $45 \mathrm{~mL}$ 를 섞어 $\mathrm{pH}$ 8.2가 될 때까지 $0.1 \mathrm{~N} \mathrm{NaOH}$ 로 적정하였다. 아래의 식으로 산도를 산출하였다.

산도 $(\%)=$ $\frac{0.009 \times \mathrm{NaOH} \text { 소비량 }(\mathrm{mL}) \times \mathrm{NaOH} \text { factor }}{\text { 시료무게 }(\mathrm{g})} \times 100 \times$ 희석배수

\section{색도 측정}

홍시 스프레드의 색도 측정은 백색판 $(\mathrm{L}=100, \mathrm{a}=0, \mathrm{~b}=0)$ 으 로 보정된 색차계(CM-5, Minolta Co., Osaka, Japan)를 사용 하여 측정하였다. 시료의 명도(lightness), 적색도(redness), 황색도(yellowness)를 3 회 측정하여 평균값으로 나타내었다.

\section{점도 측정}

홍시 스프레드의 발림성을 확인하기 위해 점도를 측정하 였으며, 이는 점도계(DV-IIViscometer, AMETEK Brookfield, Middleborough, MA, USA)를 이용하여 시료 $50 \mathrm{~g}$ 을 점도용 spindle No.7인 spindle에 회전속도 $50 \mathrm{rpm}$ 에서 1 분간 작동 시킨 후 값을 3 회 측정하여 평균값으로 나타내었다.

\section{가용성 탄닌 함량 측정}

탄닌은 폴리페놀의 일부로 그 함량을 Folin-Denis법(Tambe 와 Bhambar, 2014)에 의해 측정하였다. 시료 $1 \mathrm{~g}$ 에 증류수 $45 \mathrm{~mL}$ 를 넣은 후 1 분간 잘 교반하여 $5,000 \mathrm{rpm}$ 으로 $4{ }^{\circ} \mathrm{C}$ 에서 10 분간 원심분리한 후 얻어진 상등액을 시료액으로 사용하 였다. 시료액 $100 \mu \mathrm{L}$ 에 $2 \%$ sodium carbonate $2 \mathrm{~mL}$ 와 $50 \%$ Folin-Ciocalteu's phenol reagent $100 \mu \mathrm{L}$ 를 가한 후 30 분간 반응시킨 후 증류수 $8 \mathrm{~mL}$ 를 넣고 $720 \mathrm{~nm}$ 에서 흡광도를 측 정하였으며, gallic acid의 검량선에 의하여 함량을 산출하였 으며 3번 반복 측정하여 희석배수(10배)를 곱한 값을 그 평균 값을 나타내었다.

\section{Lycopene 함량 측정}

Lycopene 함량은 LVHEM법(The Low Volume Hexane Extraction Method)에 의해 측정하였다(Alda 등, 2009). Tannin 실험과 동일한 방법으로 추출된 시료액 $100 \mu \mathrm{L}$ 에 hexane : ethanol : acetone $(2: 1: 1 \mathrm{v} / \mathrm{v})$ 용액을 넣어 교반 후 암실에서 10 분 이상 반응시켰다. 반응이 끝난 후 증류수 1 $\mathrm{mL}$ 를 잘 섞은 후 암실에서 10 분 이상 정치시키고, 상등액을 취하여 $503 \mathrm{~nm}$ 에서 흡광도를 측정하였다.

Table 1. Formulas of persimmon spread processed with various saccharides

\begin{tabular}{ccccc}
\hline Samples & Soft persimmon (\%) & Saccharide (\%) & Locust bean gum (\%) \\
\hline CON1 & 59.7 & Sugar & 40 & 0.3 \\
CON2 & 79.7 & Sugar & 20 & 0.3 \\
XLT & 79.7 & Xylitol & 20 & 0.3 \\
IMO & 79.7 & Isomalto-oligosaccharide & 20 & 0.3 \\
FTO & 79.7 & Fructo-oligosaccharide & 20 & 0.3 \\
MTD & 79.7 & Maltodextrin & 20 & 0.3 \\
\hline
\end{tabular}




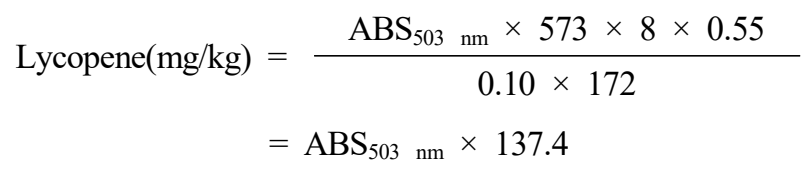

$573(\mathrm{~g} / \mathrm{mole})$ : lycopene 분자량

$8(\mathrm{~mL})$ : 혼합 용액량

0.55 : 혼합용액 상등액 비율

$0.10 \mathrm{~g}$ : 시료량

172 $\left(\mathrm{mM}^{-1}\right)$ : n-hexane에 추출되는 lycopene 계수

\section{포도당 흡수지연 효과}

다양한 홍시 스프레드의 포도당 흡수지연 효과를 확인하기 위하여 다음과 같은 과정으로 진행하였다. 모든 시료를 $1 \%$ 농 도 $(\mathrm{w} / \mathrm{v})$ 로 증류수에 희석한 용액을 균질화한 후 $95^{\circ} \mathrm{C}$ 에서 5 분간 가열하고 15 분간 방냉하였다. 이 용액에 포도당의 농도 가 $100 \mathrm{mM} / \mathrm{L}$ 가 되도록 완전히 녹인 후 포도당을 녹인 용액 $25 \mathrm{~mL}$ 를 투석막(Sigma D7884 : M.W. Cut-off<1200) 안에 넣고 증류수 $200 \mathrm{~mL}$ 가 담긴 비커에 담궈 $37^{\circ} \mathrm{C}$ 의 항온수조에 넣고 교반했다. $15,30,60,90,120,180$ 분마다 투석액 $1 \mathrm{~mL}$ 씩 수집하여 포도당 함량을 구하였다. Blank는 시료 없이 $100 \mathrm{mM} / \mathrm{L}$ 포도당 용액 $25 \mathrm{~mL}$ 만을 투석막에 넣고 증류수 $200 \mathrm{~mL}$ 가 담긴 비커에 담궈 동일한 시간마다 투석액을 수집 하여 포도당 함량을 구하였다(Park 등, 2007). 포도당 함량은 환원당 측정 방법에 의해 측정하였으며, 3회 반복 측정하여 평균값으로 나타냈다.

\section{통계처리}

실험 결과는 3 회 반복 측정한 평균치로 나타내었고, $\mathrm{R}$ Program(www.r-project.org)을 이용하여 분산 분석과 상관 분석을 실시하였으며, 시료간의 유의성 검정은 $\mathrm{p}<0.05$ 수준 에서 Duncan's multiple range test로 하였다.

\section{결과 및 고찰}

\section{원료 홍시의 이화학적 특성}

본 실험에 사용된 원료 홍시의 품질특성을 분석한 결과는 Table 2에 나타내었다. 홍시의 수분 함량은 $82.09 \%$, 조단백 질은 $0.44 \%$, 조지방은 $0.02 \%$, 조회분은 $0.33 \%$, 탄수화물은 $17.10 \%$, 조섬유는 $0.35 \%$ 로 나타났다. 2014년 농촌진흥청 농 식품 종합정보시스템에서 발행된 식품성분표에 의하면 홍시 의 수분 $84.4 \%$, 조단백질은 $0.2 \%$, 조지방은 $0.2 \%$, 조회분은 $0.4 \%$ 로 나타나, 본 연구결과와 약간의 차이는 있으나, 이는 홍시의 품종과 수확시기에 의한 차이인 것으로 보이며, 조지 방을 제외한 나머지 분석항목 결과의 범위는 유사한 것으로
Table 2. Various quality characteristics of soft persimmon

\begin{tabular}{|c|c|}
\hline Quality characteristics & Value \\
\hline Moisture (\%) & $82.09 \pm 1.41^{1)}$ \\
\hline Crude protein $(\%)$ & $0.44 \pm 0.01$ \\
\hline Crude fat $(\%)$ & $0.02 \pm 0.01$ \\
\hline Crude ash $(\%)$ & $0.33 \pm 0.06$ \\
\hline Carbohydrate $(\%)$ & $17.10 \pm 1.44$ \\
\hline Crude fiber $(\%)$ & $0.35 \pm 0.02$ \\
\hline Soluble solid ( ${ }^{\circ}$ Brix) & $18.43 \pm 0.32$ \\
\hline Reducing sugar (mg/g) & $43.90 \pm 0.10$ \\
\hline $\mathrm{pH}$ & $5.81 \pm 0.01$ \\
\hline Acidity (\%) & $0.18 \pm 0.02$ \\
\hline Soluble tannin content $(\mu \mathrm{g} / \mathrm{mg})$ & $0.31 \pm 0.02$ \\
\hline \multirow{3}{*}{ Color $\left.^{2}\right)$} & $44.42 \pm 1.13$ \\
\hline & $30.80 \pm 0.49$ \\
\hline & $57.61 \pm 0.32$ \\
\hline
\end{tabular}

${ }^{1)}$ Values are mean $\pm \mathrm{SD}(\mathrm{n}=3)$.

${ }^{2} \mathrm{~L}$, lightness; a, redness; b, yellowness.

나타났다.

가용성 고형분 및 환원당은 각각 $18.43{ }^{\circ} \mathrm{Brix}$ 와 $43.9 \mathrm{mg} / \mathrm{g}$ 으로 감 유전자원 도감(2012)의 감 품종별 당도와 유사하게 나타났다. $\mathrm{pH}$ 및 산도는 각각 $5.81,0.18 \%$ 로 나타났고, 잼을 제조하기 위한 적정 조건으로 $\mathrm{pH}$ 는 2.5-3.2(Chae, 2001)로, 홍시는 잼의 원료로 적합하지 않았다. 때문에 겔화제인 로커 스트콩검을 첨가한 홍시 스프레드를 제조하기 위해 적합 배 합비율을 사전에 확인하였다. 홍시의 색도 측정 결과, $\mathrm{L}$ 값은 $44.42, \mathrm{a}$ 값은 $30.80, \mathrm{~b}$ 값은 57.61 로 나타났다.

\section{원료 홍시의 기능적 특성}

스프레드 제조에 사용된 원료 홍시의 가용성 tannin 함량, 포도당 흡수 지연 효과 분석 결과는 Table 2, Fig. 1에 나타내 었다. 홍시는 떫은 감으로 만들어지며, 이 떫은감은 가공 후 제품에 떫은맛을 잔존하는 문제점이 제기되고 있다(Matsuo 와 Ito, 1978). 원료 홍시의 가용성 tannin 함량은 $0.31 \mu \mathrm{g} / \mathrm{mg}$ 으로 사람이 맛을 보았을 때 떫은맛을 느낄 수 없는 정도로 나타났다. Seo 등(1999)의 연구에서 떫은감의 가용성 탄닌 함량은 녹숙감이 $14.40 \mu \mathrm{g} / \mathrm{mg}$, 완숙감 $6.40 \mu \mathrm{g} / \mathrm{mg}$, 홍시 $0.40 \mu \mathrm{g} / \mathrm{mg}$ 으로 성숙도에 따라 떫은맛이 유의적으로 낮아지 는 경향을 나타냈고, 홍시일 때 유독 가용성 탄닌 함량이 감 소한 것을 확인할 수 있었다. 이는 본 연구에서 홍시의 가용 


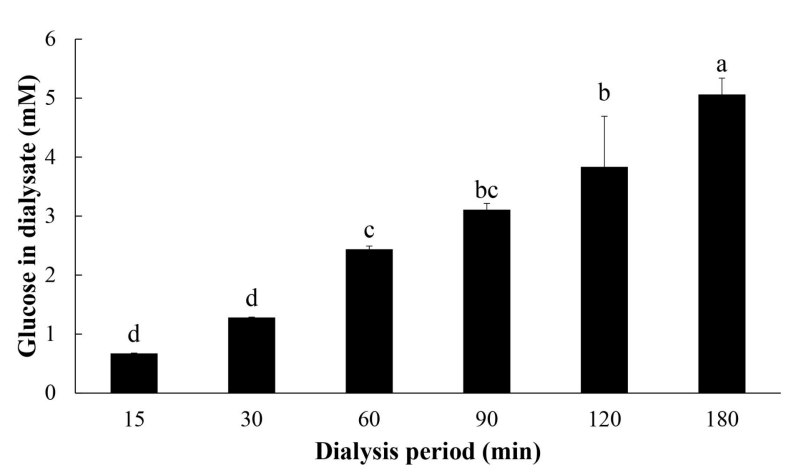

Fig. 1. Glucose movement across dialysis bag in the presence of soft persimmon.

Mean \pm SD $(n=3)$ with different letters are significantly different at $5 \%$ level.

성 탄닌 함량 결과값과 유사하게 나타났다. 따라서 홍시를 이 용해 제조된 스프레드에서 떫은맛에 의한 문제는 없을 것으 로 보인다. 포도당 흡수 지연 효과 분석은 in vitro법에 의하 여 영양소에 대한 식이섬유의 가둠 효과를 이용하여 투석막 을 통해 투석되는 포도당의 양을 측정한 것이다(Adiotomre 등, 1990). $1 \%$ 로 희석한 홍시에 포도당 $100 \mathrm{mM} / \mathrm{L}$ 를 녹인 후 투석막 내에 시료를 넣고 투석막을 통해 투석되는 포도당 을 3시간 동안 일정시간 간격으로 측정하였으며, 그 결과를 포도당 투과량 $(\mathrm{mM})$ 은 Fig. 1에 나타내었다. Blank는 시료 없 이 $100 \mathrm{mM}$ 포도당 용액의 투석액을 측정한 값으로 홍시는 Blank의 포도당 투석액에 비해 20-53\%로 포도당의 투과를 지연시킴을 알 수 있는데, 이는 홍시의 식이섬유가 그 구조 내에 포도당을 가두어 두는 효과(Schneeman, 1987)에 기인 하는 것으로 생각된다. 일반적으로 보수력과 점성이 높은 수 용성 식이섬유에서 포도당 흡수 억제지수가 높은 것으로 알 려지고 있으므로(Hhu, 1999) 홍시의 식이섬유가 포도당 흡
수 지연 효과가 있는 것으로 보인다.

\section{기능성당 첨가 홍시 스프레드의 일반 특성}

기능성 당을 첨가하여 제조한 홍시 스프레드의 수분, 탄수 화물, 조지방, 조회분, 조섬유 함량은 Table 3에 나타내었다. 수분함량의 경우, $\mathrm{CON} 1$ 는 $33.2 \%$ 로 가장 낮았으며, 당류 첨 가량이 $20 \%$ 로 제조된 저당도 홍시 스프레드(CON2, XLT, $\mathrm{IMO}, \mathrm{FTO}, \mathrm{MTD})$ 는 50.0-58.2\%로 CON1에 비하여 수분함 량이 감소하는 경향을 나타내었다. 또한 $\mathrm{CON} 2$ 에 비하여 기 능성 당 사용 홍시 스프레드의 수분함량이 높게 나타났는데, 이는 기능성 당이 수분보습효과가 뛰어나다는 특징 때문이다 (Ha와 Lee, 1999). IMO가 FTO보다 수분함량이 더 높은 것 으로 이소말토 올리고당이 프락토 올리고당보다 수분보습력 이 더 우수한 것을 알 수 있다. 조단백질 함량은 $\mathrm{CON} 1$ 이 $0.33 \%, \mathrm{CON} 2, \mathrm{XLT}, \mathrm{IMO}, \mathrm{FTO}, \mathrm{MTD}$ 가 $0.49-0.58 \%$ 로 당 류의 첨가 비율이 낮을 때 조단백질의 함량이 상대적으로 높 은데, 이는 당류 첨가 비율이 낮은 대신 홍시의 비율이 높기 때문인 것으로 사료된다. 조지방 함량은 $0.02-0.10 \%$, 조회분 함량은 $0.22-0.47 \%$ 로 유의적 차이는 거의 없었다. 탄수화물 함량은 $\mathrm{CON} 1$ 이 $66.23 \%$ 로 가장 높았고, 나머지 구들은 $40.84-49.70 \%$ 로 상대적으로 낮았다. 탄수화물 함량은 수분 함량에 반비례적으로 나타났다. 조섬유 함량은 유의적 차이 가 없었다.

\section{기능성당 첨가 홍시 스프레드의 이화학적 특성}

기능성 당의 종류를 달리하여 제조한 홍시 스프레드의 이 화학적 품질 특성(가용성 고형분, 환원당, $\mathrm{pH}$, 총산도, 색도) 분석 결과는 Table 4 와 같다. 당 첨가량과 당 종류에 따른 가 용성 고형분 함량은 유의적인 차이가 있었다. CON1은 59.33 ${ }^{\circ} \mathrm{Brix}$ 로 가장 높았다. Kwon(2015)은 올리고당의 종류와 첨

Table 3. Proximate composition in soft persimmon spread prepared with various saccharides

\begin{tabular}{ccccccc}
\hline Samples $^{1)}$ & CON1 & CON2 & XLT & IMO & FTO & MTD \\
\hline Moisture & $33.18 \pm 1.74^{2)(3)}$ & $50.07 \pm 1.00^{\mathrm{b}}$ & $51.77 \pm 1.10^{\mathrm{b}}$ & $58.16 \pm 4.44^{\mathrm{a}}$ & $52.80 \pm 2.87^{\mathrm{b}}$ & $49.40 \pm 2.86^{\mathrm{b}}$ \\
Crude protein & $0.33 \pm 0.01^{\mathrm{c}}$ & $0.55 \pm 0.01^{\mathrm{ab}}$ & $0.47 \pm 0.10^{\mathrm{b}}$ & $0.58 \pm 0.03^{\mathrm{a}}$ & $0.58 \pm 0.06^{\mathrm{a}}$ & $0.29 \pm 0.03^{\mathrm{a}}$ \\
Crude fat & $0.03 \pm 0.00^{\mathrm{b}}$ & $0.04 \pm 0.01^{\mathrm{b}}$ & $0.03 \pm 0.00^{\mathrm{b}}$ & $0.10 \pm 0.08^{\mathrm{a}}$ & $0.02 \pm 0.01^{\mathrm{b}}$ & $0.05 \pm 0.01^{\mathrm{ab}}$ \\
Crude ash & $0.22 \pm 0.01^{\mathrm{c}}$ & $0.35 \pm 0.02^{\mathrm{b}}$ & $0.49 \pm 0.03^{\mathrm{a}}$ & $0.32 \pm 0.04^{\mathrm{b}}$ & $0.37 \pm 0.02^{\mathrm{b}}$ & $0.56 \pm 0.05^{\mathrm{bc}}$ \\
Carbohydrate & $66.23 \pm 1.72^{\mathrm{a}}$ & $48.99 \pm 1.02^{\mathrm{b}}$ & $47.24 \pm 1.10^{\mathrm{b}}$ & $40.84 \pm 4.48^{\mathrm{c}}$ & $46.22 \pm 2.79^{\mathrm{b}}$ & $49.70 \pm 2.88^{\mathrm{b}}$ \\
Crude fiber & $0.23 \pm 0.06^{\mathrm{c}}$ & $0.26 \pm 0.15^{\mathrm{c}}$ & $0.44 \pm 0.06^{\mathrm{ab}}$ & $0.33 \pm 0.08^{\mathrm{bc}}$ & $0.29 \pm 0.04^{\mathrm{bc}}$ & $0.49 \pm 0.04^{\mathrm{a}}$ \\
\hline
\end{tabular}

${ }^{1)} \mathrm{CON} 1$, soft persimmon spread with $40 \%$ sugar; CON2, soft persimmon spread with $20 \%$ sugar; XLT, soft persimmon spread with xylitol; IMO, soft persimmon spread with isomalto-oligosaccharide; FTO, soft persimmon spread with fructo-oligosaccharide; MTD, soft persimmon spread with maltodextrin.

${ }^{2)}$ Values are mean \pm SD.

${ }^{3)-c}$ Mean in a row by different superscripts are significantly different at the $\mathrm{p}<0.05$. 
Table 4. Soluble solid, reducing sugar content, $\mathrm{pH}$, total acidity of soft persimmon spread prepared with various saccharides

\begin{tabular}{|c|c|c|c|c|c|c|c|}
\hline Samples ${ }^{1)}$ & $\begin{array}{l}\text { Soluble solid } \\
\quad\left({ }^{\circ} \text { Brix }\right)\end{array}$ & $\begin{array}{l}\text { Reducing sugar } \\
(\mathrm{mg} / \mathrm{g})\end{array}$ & $\mathrm{pH}$ & $\begin{array}{c}\text { Total acidity } \\
(\%)\end{array}$ & $\mathrm{L}^{2)}$ & $\mathrm{a}$ & $\mathrm{b}$ \\
\hline CON1 & $59.33 \pm 2.08^{3) c 4)}$ & $199.9 \pm 87.3^{\mathrm{cd}}$ & $4.82 \pm 0.22^{\mathrm{a}}$ & $0.12 \pm 0.03^{\mathrm{a}}$ & $28.62 \pm 0.25^{\mathrm{b}}$ & $3.27 \pm 0.22^{\mathrm{c}}$ & $7.37 \pm 0.22^{b}$ \\
\hline CON2 & $46.67 \pm 0.58^{\mathrm{b}}$ & $173.5 \pm 16.0^{\mathrm{d}}$ & $4.43 \pm 0.11^{b}$ & $0.14 \pm 0.01^{\mathrm{a}}$ & $32.57 \pm 0.22^{\mathrm{a}}$ & $5.82 \pm 0.37^{\mathrm{ab}}$ & $11.53 \pm 0.23^{\mathrm{a}}$ \\
\hline XLT & $45.67 \pm 1.33^{\mathrm{b}}$ & $190.5 \pm 16.5^{\mathrm{cd}}$ & $4.51 \pm 0.01^{\mathrm{b}}$ & $0.14 \pm 0.03^{\mathrm{a}}$ & $32.73 \pm 0.23^{\mathrm{a}}$ & $5.63 \pm 0.23^{\mathrm{b}}$ & $12.06 \pm 0.95^{\mathrm{a}}$ \\
\hline IMO & $41.00 \pm 2.65^{\mathrm{a}}$ & $301.1 \pm 24.8^{\mathrm{ab}}$ & $4.06 \pm 0.03^{\mathrm{c}}$ & $0.12 \pm 0.01^{\mathrm{a}}$ & $32.99 \pm 0.36^{\mathrm{a}}$ & $5.98 \pm 0.28^{\mathrm{ab}}$ & $12.07 \pm 0.48^{\mathrm{a}}$ \\
\hline FTO & $42.67 \pm 1.53^{b}$ & $255.9 \pm 11.6^{\mathrm{bc}}$ & $3.84 \pm 0.03^{\mathrm{d}}$ & $0.14 \pm 0.02^{\mathrm{a}}$ & $32.80 \pm 0.74^{\mathrm{a}}$ & $6.54 \pm 0.35^{\mathrm{ab}}$ & $12.49 \pm 0.49^{\mathrm{a}}$ \\
\hline MTD & $50.70 \pm 2.75^{\mathrm{b}}$ & $338.4 \pm 17.1^{\mathrm{a}}$ & $4.62 \pm 0.12^{\mathrm{b}}$ & $0.14 \pm 0.02^{\mathrm{a}}$ & $34.32 \pm 2.69^{\mathrm{a}}$ & $7.41 \pm 2.12^{\mathrm{a}}$ & $13.81 \pm 3.66^{\mathrm{a}}$ \\
\hline
\end{tabular}

${ }^{1)} \mathrm{CON} 1$, soft persimmon spread with $40 \%$ sugar; CON2, soft persimmon spread with $20 \%$ sugar; XLT, soft persimmon spread with xylitol; IMO, soft persimmon spread with isomalto-oligosaccharide; FTO, soft persimmon spread with fructo-oligosaccharide; MTD, soft persimmon spread with maltodextrin.

${ }^{2)} \mathrm{L}$, lightness; a, redness; b, yellowness.

${ }^{3)}$ Values are mean $\pm \mathrm{SD}$.

4)a-d Mean in a column by different superscripts are significantly different at the $\mathrm{p}<0.05$.

가량을 달리한 블루베리 잼의 연구에서 설탕을 첨가한 잼이 올리고당을 첨가한 잼에 비하여 유의적으로 가용성 고형분 함량이 높아진다고 보고하였는데, 본 연구 결과와 일치하였 다. 기능성 당은 설탕에 비하여 $30-50 \%$ 의 낮은 감미도를 가 지므로 이러한 결과가 나타난 것으로 판단된다. 환원당 함량 은 CON2가 $173.5 \mathrm{mg} / \mathrm{g}$ 으로 가장 낮게 측정되었으며, 이소 말토 올리고당, 프락토 올리고당, 말토덱스트린은 각각 301.1 $\mathrm{mg} / \mathrm{g}, 255.9 \mathrm{mg} / \mathrm{g}, 338.4 \mathrm{mg} / \mathrm{g}$ 으로 비교적 높은 환원당 함량 이 나타났다. 이는 호박잼 제조 시 설탕만 첨가한 대조군에 비해 프락토 올리고당 처리구의 환원당 함량이 높게 나타났 다는 송 등(2004)의 연구 결과와 유사하였다. $\mathrm{pH}$ 측정 결과, 시료간 큰 유의적 차이는 없었다. 이는 프락토 올리고당을 첨 가한 양파잼과, 딸기잼이 유의적 차이가 없었다는 연구결과 (Islam 등, 2012)와 일치하여, 기능성 당을 첨가는 잼과 스프 레드의 $\mathrm{pH}$ 에 큰 영향을 주지 않는 것으로 보인다. 산도의 경 우도 $0.12-0.14 \%$ 로 모든 시료 간 유의적 차이가 없었으며, 원 료인 홍시의 산도보다 낮게 측정되었는데, 이것은 스프레드 제조 시 일부 젤리화 현상에 결합된 것으로 보인다. 가용성 탄닌 함량 분석 결과, 시료 간 유의적 차이는 나타나지 않았 다. 홍시스프레드 L값은 $\mathrm{CON} 1$ 이 28.62로 유의적으로 가장 낮았으며, 나머지 시료들은 서로 차이가 나타나지 않았다. a 값은 $\mathrm{FTO}$ 와 $\mathrm{MTD}$ 는 각각 6.54 와 7.41로 가장 높게 나타나 매우 붉은 모습을 보였다. 홍시의 주요 색소인 carotenoid( $\alpha$ carotene, $\beta$-carotene, lycopene 및 retinol)는 붉은 색을 나타 낸다(Zhou 등, 2011). Matioli와 Rodriguez의 연구(Matioli와 Rodiguez-Amaya, 2003)에서, dextrin은 carotenoid의 항산화 및 이성질체화 방지 등의 효과를 가지고 있다고 보고하여, 말 토덱스트린을 첨가한 MDT에서 더욱 붉은 황색을 띠는 것으 로 보인다. $\mathrm{CON} 1$ 은 $\mathrm{L}, \mathrm{a}, \mathrm{b}$ 값 모두 유의적으로 가장 낮게
나타나 관능적으로 좋지 않았을 것으로 사료된다. 또한 모든 스프레드시료는 원료의 홍시보다 $\mathrm{L}, \mathrm{a}, \mathrm{b}$ 값이 낮게 측정되었 는데, 이는 가열하는 제조 과정에서 홍시의 천연 색소가 파괴 되었기 때문인 것으로 보인다. 점도는 유동식품의 흐름성에 대한 저항성을 나타낸다.

홍시 스프레드의 점도 분석 결과는 Fig. 2에 나타내었다. MTD, XLT, CON2, FTO, IMO, CON1 순으로 높게 나타났으 며, 비교적 유의미한 차이가 나타났다. 자일리톨을 첨가한 자 두잼은 설탕을 첨가한 자두잼보다 점도가 높았으며(Oliverira 등, 2013), 이는 자일리톨이 흡습성이 강하여 점도가 증가하 였다고 보고하였는데, 본 연구 결과와 일치하였다. 본 연구에

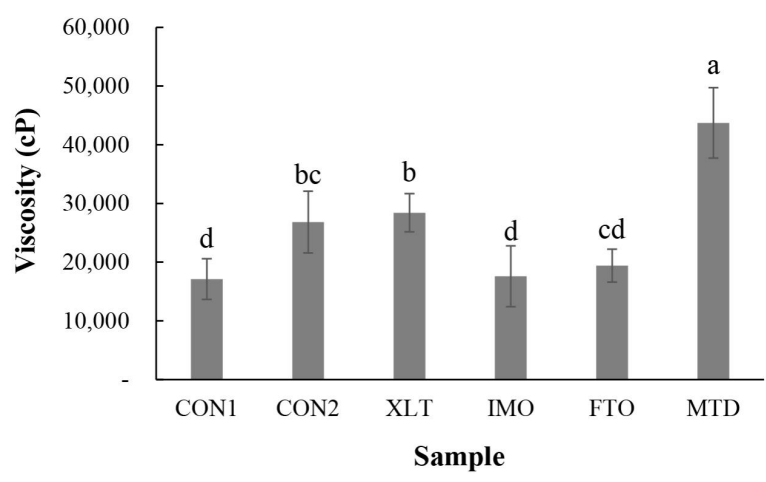

Fig. 2. Viscosity of soft persimmon spread prepared with various saccharides

CON1, soft persimmon spread with $40 \%$ sugar; CON2, soft persimmon spread with $20 \%$ sugar; XLT, soft persimmon spread with xylitol; IMO, soft persimmon spread with isomalto-oligosaccharide; FTO, soft persimmon spread with fructo-oligosaccharide; MTD, soft persimmon spread with maltodextrin.

Mean \pm SD $(n=3)$ with different letters are significantly different at $5 \%$ level. 
서 $\mathrm{MTD}$ 의 점도가 $43,733 \mathrm{cP}$ 로 가장 높게 나타났는데, 딸기 잼에 말토덱스트린을 함량을 다르게 하여 첨가하였을 시, 말 토덱스트린이 함량이 높을수록 경도가 유의적으로 증가했다 는 연구 결과로 설명할 수 있다(Kang과 Cho, 2008). 말토덱 스트린이 부분적으로 노화되어(Kim과 Shin, 2003) 이러한 결과가 나타난 것으로 보인다. 결론적으로 $\mathrm{IMO}$ 가 기능성 당 첨가구 중 가장 낮은 점도를 나타내 스프레드의 발림성이 좋 을 것으로 보인다.

\section{기능성당 첨가 홍시 스프레드의 기능적 특성}

다양한 홍시 스프레드의 lycopene 함량과 포도당 흡수 지 연 효과와 같은 기능적 특성을 측정한 결과는 Table 5, Fig. 3 과 같다. Lycopene 분석 결과, $\mathrm{IMO}$ 와 $\mathrm{FTO}$ 는 각각 58.99 , $52.26 \mathrm{mg} / \mathrm{kg}$ 으로 가장 높았는데, 이는 Goiffon 등(1999)이 올리고당과 색소(carotenoid, anthocyan 등)의 결합으로 열과 산소에 파괴되지 않고 유지된다고 보고와 유사했다. 포도당 흡수 지연 효과 분석 결과, XLT가 유의적으로 glucose 투석 량이 가장 높았으며, MTD는 15 분부터 3시간까지 지속적으 로 투석량이 유의적으로 낮은 것을 확인할 수 있었다. 이와 같은 결과로, 말토덱스트린은 스프레드에 첨가 시 포도당 흡 수 지연 효과를 나타낸다고 할 수 있으며, 말토덱스트린이 포 도당을 가둠 효과가 가장 우수한 것으로 보인다. 따라서 말토 덱스트린을 첨가한 홍시스프레드는 항당뇨 효과가 기대된다. 말토덱스트린 이외의 당 종류들은 glucose 투석량에서 유의 적 차이가 나타나지 않아 포도당 흡수 효과는 비슷할 것으로 사료된다.

Table 5. Soluble tannin and lycopene content of soft persimmon spread prepared with various saccharides

\begin{tabular}{ccc}
\hline Samples $^{1)}$ & $\begin{array}{c}\text { Soluble tannin content } \\
(\mu \mathrm{g} / \mathrm{mg})\end{array}$ & $\begin{array}{c}\text { Lycopene } \\
(\mathrm{mg} / \mathrm{kg})\end{array}$ \\
\hline CON1 & $0.10 \pm 0.01^{2) \mathrm{a} 3)}$ & $47.13 \pm 2.54^{\mathrm{b}}$ \\
CON2 & $0.11 \pm 0.01^{\mathrm{a}}$ & $45.20 \pm 4.41^{\mathrm{b}}$ \\
XLT & $0.11 \pm 0.01^{\mathrm{a}}$ & $46.49 \pm 1.47^{\mathrm{b}}$ \\
IMO & $0.13 \pm 0.02^{\mathrm{a}}$ & $58.99 \pm 6.82^{\mathrm{a}}$ \\
FTO & $0.12 \pm 0.02^{\mathrm{a}}$ & $52.26 \pm 2.59^{\mathrm{a}}$ \\
MTD & $0.10 \pm 0.00^{\mathrm{a}}$ & $44.56 \pm 3.88^{\mathrm{b}}$ \\
\hline
\end{tabular}

${ }^{1)} \mathrm{CON} 1$, soft persimmon spread with $40 \%$ sugar; CON2, soft persimmon spread with 20\% sugar; XLT, soft persimmon spread with xylitol; IMO, soft persimmon spread with isomalto-oligosaccharide; FTO, soft persimmon spread with fructo-oligosaccharide; MTD, soft persimmon spread with maltodextrin.

${ }^{2)}$ Values are mean \pm SD.

${ }^{3) a, b}$ Mean in a column by different superscripts are significantly different at the $\mathrm{p}<0.05$.

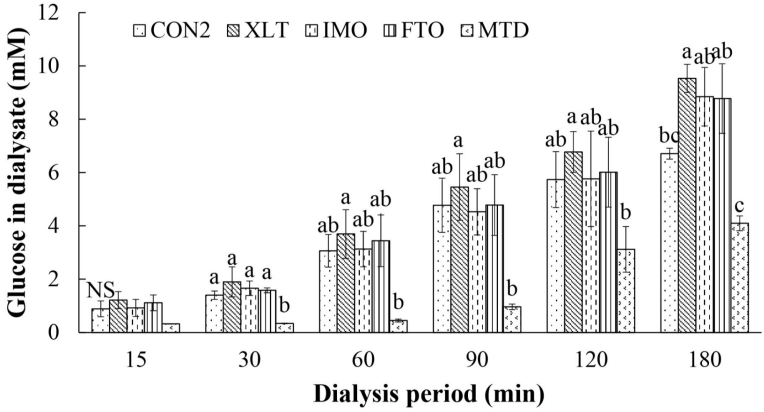

Fig. 3. Glucose movement across dialysis bag in the presence of soft persimmon spread prepared with various saccharides.

CON2, soft persimmon spread with $20 \%$ sugar; XLT, soft persimmon spread with xylitol; IMO, soft persimmon spread with isomaltooligosaccharide; FTO, soft persimmon spread with fructo-oligosaccharide; MTD, soft persimmon spread with maltodextrin.

Mean $\pm \mathrm{SD}(\mathrm{n}=3)$ with different letters are significantly different at $5 \%$ level.

\section{요 약}

스프레드는 기타 잼류로 분류되며, 제조 시 사용되는 과다 한 설탕의 양을 줄이고자 기능성 당 첨가 홍시 스프레드를 제조하고 첨가 당의 종류(자일리톨, 프락토 올리고당, 이소말 토 올리고당, 말토덱스트린)에 따른 품질 특성을 비교하였다. 홍시의 일반성분의 수분함량은 $82.09 \%$, 조단백질의 $0.44 \%$, 조지방은 $0.02 \%$, 조회분은 $0.33 \%$, 탄수화물은 $17.10 \%$ 그리 고 조섬유는 $0.35 \%$ 로 나타났다. 당도는 $18.4{ }^{\circ} \mathrm{Brix}, \mathrm{pH}$ 는 5.81 , 산도는 $0.18 \%$ 로 나타났으며, 색도는 $\mathrm{L}$ 은 $44.42, \mathrm{a}$ 는 $30.80, \mathrm{~b}$ 는 57.61 로 나타났다. 기능성 당을 첨가한 스프레드의 가용성 고형분함량은 대조군 1 이 $60^{\circ} \mathrm{Brix}$ 로 가장 높았으며, 이소말토 올리고당 처리구가 $41^{\circ} \mathrm{Brix}$ 로 가장 낮아, 건강을 위한 저당도 스프레드를 제조하기 위한 목적에 적합하였다. 홍시 스프레드의 $\mathrm{pH}$, 산도, 색도 및 가용성 탄닌 함량은 첨가 당 종류에 따라 차이가 나타나지 않았다. 점도는 말토덱스트 린 처리구가 $43,733 \mathrm{cP}$ 로 가장 높은 값을 나타내었으며, 이소 말토 올리고당 처리구가 $17,600 \mathrm{cP}$ 로 가장 낮은 값을 나타내 었다. Lycopene 함량은 이소말토 올리고당 처리구가 58.99 $\mathrm{mg} / \mathrm{kg}$ 으로 가장 높은 함량을 나타내었으며, 프락토 올리고 당 처리구가 $52.26 \mathrm{mg} / \mathrm{kg}$ 으로 다음으로 높은 함량을 나타내 었다. 말토덱스트린 처리구는 포도당이 투과량을 조사한 결 과, 포도당 흡수 지연 효과가 높은 것으로 나타났으나, 그에 비해 점도가 높아 발림성이 좋지 못하고 가용성 고형분, 환원 당 함량이 높으며, lycopene 함량이 비교적 낮아, 당도 저감 및 기능성 향상을 위한 당으로는 적합하지 않을 것으로 보인 다. 따라서 기능성 당 첨가 홍시 스프레드 제조에는 낮은 당 도, 낮은 점도, 높은 lycopene 함량을 나타내는 이소말토 올 
리고당을 사용하는 것이 가장 적합한 것으로 판단된다.

\section{Conflict of interests}

The authors declare no potential conflict of interest.

\section{ORCID}

Ji-Young Choi https://orcid.org/0000-0002-7854-9277 Kwang-Deog Moon

https://orcid.org/0000-0001-5277-3345

\section{References}

Adiotomre J, Eastwood MA, Edwards CA, Brydon WG. Dietary fiber; In vitro methods that anticipate nutrition and metabolic activity in humans. Am J Clin Nutr, 52, 128-134 (1990)

Alda LM, Gogoasa I, Bordean DM, Gergen I, Alda S, Moldovan C, Nita L. Lycopene content of tomatoes and tomato products. J Agroaliment Processes Technol, 15, 540-542 (2009)

An HL, Heo SJ, Lee KS. Quality characteristics of muffins with xylitol. Korean J Culi Res, 16, 307-316 (2010)

Choi YS, Kim HW, Hwang KE, Kim CJ, Lee HM, Kim OK, Choi KS, Chung HJ. Effects of replacing sugar with xylitol and sorbitol on the textural properties and sensory characteristics of Injeolmi. Korean $\mathrm{J}$ Food Cookery Sci, 29, 825-831 (2013)

de Ancos B, Gonzalez E, Pilar MP. Effect of high-pressure treatment on the carotenoid composition and the radical scavenging activity of persimmon fruit purees. J Agric Food Chem, 48, 3542-3548 (2000)

Felber JP, Tappy L, Vouillamoz D, Randin JP, Jequier E. Comparative study of maltitol and sucrose by means of continuous indirect calorimetry. J Parenter Enteral Nutr, 11, 250-254 (1987)

Giovannucci E, Rimm EB, Lin Y, Stampfer J, Willett WC. A prospective study of tomato products, lycopene and prostate cancer risk. J Nat Cancer Inst, 94, 391-398 (2002)

Goiffon JP, Mouly PP, Gaydou EM. Anthocyanic pigment determination in red fruit juices, concentrated juices and syrups using liquid chromatography. Anal Chim Acta,
382, 39-50 (1999)

Ha BJ, Lee OS. Moisturizing property and physiological activity of chitosan oligosaccharide. J Soc Cosmet Sci Korea, 25, 6-22 (1999)

Heber D, Lu QY. Overview of mechanisms of action of lycopene. Exp Biol Med, 227, 920-923 (2002)

Hhu KT. Oligosaccharides. Yuhanmunhwasa, Goyang, Korea, p 88-97 (1999)

Hwang ES, Bowen PE. Effects of tomatoes and lycopene on prostate cancer prevention and treatment. J Korean Soc Food Sci Nutr, 33, 455-462 (2004)

Islam MZ, Monalisa K, Hoque MM. Effect of pectin on the processing and preservation of strawberry (Fragaria ananassa) jam and jelly. Int J Nat Sci, 2, 8-14 (2012)

Kang NE, Cho MS. Quality characteristics of strawberry jam added with various levels of resistant starch. Korean J Food Nutr, 21, 457-462 (2008)

Kim JO, Shin MS. Effect of RS3 type resistant starch prepared from nonwaxy rice starch on the properties of Injulmi. Korean J Soc Food Cookery Sci, 19, 65-71 (2003)

Kwon EY. Development and quality characteristic of blueberry jam on the types of oligosaccharide. MS Thesis, Sejong University, Korea, p 20 (2015)

Kwon HK, Yuk C. Physicochemical properties of isomaltooligosaccharide. J Korean Microbiol Biotechnol, 7, 170-175 (1994)

Lee HJ, Lim SY, Kang MG, Park JJ, Chung HJ, Yang SJ. Beneficial effects of Daebong persimmon against oxidative stress, inflammation, and immunity in vivo. J Korean Soc Food Sci Nutr, 44, 491-496 (2015)

Lee SD, Lee MH, Lee HW, Cho JK, Lee US, Sim KH. Effect of quality changes according to drying method of astringent persimmon (Diospyros kaki L.) after peeling. RDA J Agri Sci, 36, 699-704 (1994)

Ma J, Liu X, Noh KH, Kim MJ, Song YS. Protective effects of persimmon leaf and fruit extracts against acute ethanol-induced hepatotoxicity. J Food Sci Nutr, 12, 202-208 (2007)

Maguire A, Rugg-gunn J, Wright G. Adaptation of dental plaque to metabolise maltitol compared with other sweeteners. J Dent, 28, 51-59 (2000)

Malinda L, Christine AR, Susan EC, Peter M, Ross C. Children's acceptance of xylitol based foods. Community 
Dent Oral Epidemoil, 28, 97-101 (2000)

Mamede MEO, Dib de Carvalvo L, Viana ES, Alves de Oliveira L, Soares WSF, Ritzinger R. Production of dietetic jam of umbu-caja (Spondias sp.): Physical, physicochemical and sensorial evaluations. J Food Nutr Sci, 4, 461-468 (2013)

Matioli G, Rodriguez-Amaya DB. Microencapsulation of lycopene with cyclodextrins. Cienc Tecnol Aliment, 23, 102-105 (2003)

Matsuo $\mathrm{T}$, Ito $\mathrm{S}$. The chemical structure of kaki-tannin from immature fruit of the persimmon (Diospyros kaki L.). Agric Biol Chem, 42, 1637-1643 (1978)

McKee LH, Garcia-Whitehead C, Remmenga M. Quality characteristics of red raspberry fruit spread made with four sweeteners. Plant Foods Hum Nutr, 57, 343-352 (2002)

Park KY, Back JH, Hur W, Lee SY. In vitro glucose and bile acid retardation effect of fucoidan from Laminaria japonica. J Korean Biotechnol Bioeng, 22, 265-269 (2007)

Schneeman BO. Soluble vs insoluble fiber: Different physiological response. Food Tenhnol, 41, 81-82 (1987)

Seo JH, Jeong YJ, Shin SR, Kim JN, Kim KS. Changes in pattern of tannin isolated from astringent persimmon fruits. Korean J Postharvest Sci Technol, 6, 328-332 (1999)

Seo JH, Jeong YJ, Kim KS. Physiological characteristics of tannins isolated from astringent persimmon fruits. Korean J Food Sci Technol, 32, 212-217 (2000)

Seol SM, Bang MH, Jeong MK, Kim WK. Effects of high amylose starch on gut functions in rats. Korean J Nutr, 36, 109-116 (2003)

Song IS, Lee KM, Kim MR. Quality characteristics of pumpkin jam when sucrose was replaced with oligosaccharides during storage. Korean J Soc Food Cookery Sci, 20, 279-286 (2004)

Stahl W, Heinrich U, Wiseman S, Eichler O, Sies H, Tronnier H. Dietary tomato paste protects against ultraviolet light-induced erythema in human. J Nutr, 131, 1449-1451 (2001)

Tambe VD, Bhambar RS. Estimation of total phenol, tannin, alkaloid and flavonoid in Hibiscus tiliaceus Linn. wood extracts. Res Rev J Pharmacogn Phytochem, 2, 41-47 (2014)

Yun JW, Jung KH, Jeon YJ, Lee JH. Continuous production of fructo-oligosaccharides by immobilized cells of Aureobasidium pullulans. J Microbiol Biotechnol, 2, 98-101 (1992)

Yun JW. Fructooligosaccharides-occurrence, preparation, and application. Enzyme Microb Technol, 19, 107-117 (1996)

Zhou C, Zhao D, Sheng Y, Tao J, Yang Y. Carotenoids in fruits of different persimmon cultivars. Molecules, 16, 624-636 (2011) 